\title{
Yield, Water Use Efficiency and Physiological Characteristic of "Tommy Atkins" Mango under Partial Rootzone Drying Irrigation System
}

\author{
Marcelo Rocha dos Santos, Breno Rosa Neves, Bismarc Lopes da Silva, \\ Sérgio Luiz Rodrigues Donato \\ Instituto Federal de Educação, Ciência e Tecnologia Baiano, Campus Guanambi, Bahia, Brazil \\ Email: marcelo.rocha@guanambi.ifbaiano.edu.br
}

Received 6 August 2015; accepted 8 September 2015; published 11 September 2015

Copyright (C) 2015 by authors and Scientific Research Publishing Inc.

This work is licensed under the Creative Commons Attribution International License (CC BY).

http://creativecommons.org/licenses/by/4.0/

(c) (i) Open Access

\begin{abstract}
This study was conducted to evaluate the yield, water use efficiency and physiologic characteristics of "Tommy Atkins" mango under partial rootzone drying. The experiment was carried out in an orchard of mango in the irrigated perimeter of Ceraíma, BA. Five treatments and six repetitions were used with one tree per experimental plot: 01-Full Irrigation, $100 \%$ of ETc, $02-100 \%$ of ETc with frequency of alternance (FA) of 15 days, 03-80\% ETc with FA of 15 days, $04-60 \%$ of ETc with FA of 15 days, $05-40 \%$ ETc with FA of 15 days. The treatments were conductedfrom the beginning of flowering to the harvest of mango in an orchard irrigated by drip. There was no significant reduction in productivity of "Tommy Atkins" mango under PRD up to 40\% of ETc and PRD with $\mathbf{4 0 \%}$ ETc resulted in greater water use efficiency. There was no significant difference among the averages of photosynthetically active radiation, Qleaf; leaf temperature, $\mathrm{Tl}$; internal $\mathrm{CO}_{2}$ concentration, $C i$; transpiration, $E$; stomatal conductance, $g s$; photosynthesis, $A$; carboxylation efficiency, $A / C i$; quantum efficiency of photosynthesis, $A / Q l e a f$ and instantaneous water use efficiency, $A / E$ between full irrigation and PRD with different water depth. The increase in leaf temperature causes reduction in $A / Q l e a f$ and $A / E$, however, it increases the transpiration. Increased $g s$ results in higher rates of $E, A$ and $A / C i$. The use of the PRD with $40 \%$ of ETc causes no interference in gas exchange, maintains the yield and increases water use efficiency in "Tommy Atkins" mango tree.
\end{abstract}

\section{Keywords}

Irrigation Strategy, Mangifera, Regulated Deficit Irrigation 


\section{Introduction}

The northeastern region of Brazil exhibits a large diversity in terms of crops and, in regard to the irrigated crops, there are expressive improvements in productivity and quality of the products. In this region, the main hubs are in the semiarid, where there is a high water demand that is not fulfilled by natural precipitation, resulting in hydric deficits for long periods in the plant cycle, thus demanding the use of irrigation.

The fruticulture stands out in the semiarid region and the mango is among the main cultivated fruit trees, especially as exportation of fresh fruits. From the national production of mango in 2012, the northeast region accounted for $66.54 \%$. Bahia is the largest producer with $54.04 \%$ of the regional production [1] wherein Juazeiro, Livramento de Nossa Senhora, Rio Corrente, Ceraíma/Estreito and Itaberaba can be highlighted as production hubs of mango located in the semiarid of Bahia, therefore the use of irrigation is required.

The Tommy Atkins was originated in the 1920s, in Fort Lauderdade, Florida, USA, as a progeny of Haden. This cultivar is a strong tree, of medium size and dense foliage. It exhibits high productivity, regular production, high attractiveness and resistance of the fruits [2], and it responds well to flower induction [3].

In water shortage conditions, irrigation management should be performed more accurately, maximizing water use and productivity, or increasing the productivity of water. The accuracy of management relates to the availability of information about the system water-soil-plant-atmosphere.

Research has shown that the interruption of irrigation on mango crops during the flower differentiation is an interesting option; however, the irrigation should be restarted soon after, in the panicle emergence stage. [4]-[7] point out that the reduction of $50 \%$ of the amount of water applied to the fruit setting significantly reduces yield, even if supplying the hydric demand over the growing and ripping stages of the fruits.

Management strategies of irrigation that prioritize the reasonable use of water have been adopted in some regions. Among these, two methods stand out from rest: RDI (Regulated Deficit Irrigation) and PRD (Partial Root-zone Drying) [4]-[8].

Partial Rootzone Drying (PRD) or partial drying of the radicular system [8], consists of alternating the irrigation on both sides of a plant, at a frequency previously set, which the most commonly used are seven, fourteen and twenty days [9]. PRD bases on biochemical responses from the plants to achieve a balance between the vegetative and reproductive development through the hydric stress, consequently, there is a significant improvement in yield by water unit applied [10]. The dryness on one side leads to a decrease of plant transpiration without exhibiting symptoms of severe stress. In mango crops, the PRD has already been subject of research by [11]-[13], where the authors obtained positive results in water and electricity savings, improvement in the quality of the fruits and yield maintenance. However, these studies are still lack of consistent results that allow the producer to adopt the correct method for a specific edaphoclimatic condition, since the water requirement of crops relies on specific conditions (soil, climate and cultivar), thus justifying the conduction of studies on this subject.

In the north of Thailand [12] found out no significant reduction in yield and quality of mango and they affirmed that it was possible to obtain a sustainable production by using PRD at 50\% of ETc. [13] mentioned that deficit irrigation from 30 to 50\% resulted in higher use efficiency and savings of water. Similar results were found by [14] with PRD applied to a "Kent" mango orchard in the semiarid of Bahia. According to the authors, reduction of $50 \%$ in the volume of applied water results in no significant decreases of yield using PRD with alternation of 14 and 21 days.

Working with "Tommy Atkins" mango in the region of Petrolina PE, 15] observed that the yields under irrigation at $70 \%, 80 \%$ and $90 \%$ of evapotranspiration of reference (ETo) were significantly higher than the productivity at $100 \%$ of ETo. The authors concluded that the efficiency in water use, in the studied region, could be enhanced by setting the irrigation at $90 \%$ of ETo.

The adoption of irrigation management techniques that focuses on the sustainability with less water demand is of fundamental importance, mainly in semiarid regions, where the water requirement is high and the availability of this resource is smaller than that in other regions of the country [4] [5]. The practice of the efficient usage of water in irrigation should be adopted, once the agricultural sector demands high volume of water. In Brazil, irrigated crops consume $61 \%$ of the water [16]. There are evidences of waste in irrigated sites where irrigation is in general overly performed. Besides the higher waste of water, over watering can cause losses of yield, plant diseases, leaching and negative environmental impact.

Based on the above discussion and in view of the dearth of information in the literature about the use of PRD in the Brazilian semiarid, it is necessary more studies related to irrigation with reduced water depth in a specific 
production phase of the plant without causing any economical loss. This study aimed to evaluate the yield, water-use efficiency and physiological characteristics of "Tommy Atkins" mango under partial root-zone drying (PRD) in the semiarid of Bahia.

\section{Material and Methods}

\subsection{Study Area}

The study was carried out in a eutrophic FluvicNeosol (Table 1) in the experimental area of the Companhia de Desenvolvimento dos Vales do São Francisco e do Parnaíba (CODEVASF) located at the irrigated perimeter of Ceraíma in the city of Guanambi, Southwest of Bahia, Brazil (Figure 1). The geographical coordinates are $14^{\circ} 13^{\prime} 30^{\prime \prime S}, 42^{\circ} 46^{\prime} 53^{\prime \prime} \mathrm{W}, 525 \mathrm{~m}$ of altitude, and the mean annual rainfall and temperature are $680 \mathrm{~mm}$ and $25.6^{\circ} \mathrm{C}$, respectively.

\subsection{Conduction of the Experiment}

The study was based on the use of partial root-zone drying (PRD) in 'Tommy Atkins' mango, 12 years old, from flowering in August of 2011 to fruit ripening in December of 2011. It was conducted in an orchard with plants at $8 \times 4 \mathrm{~m}$ spacing. Plants were watered by drip irrigation with six emitters per plant, which each emitter had 8 $\mathrm{L} \cdot \mathrm{h}^{-1}$ of flow rate.

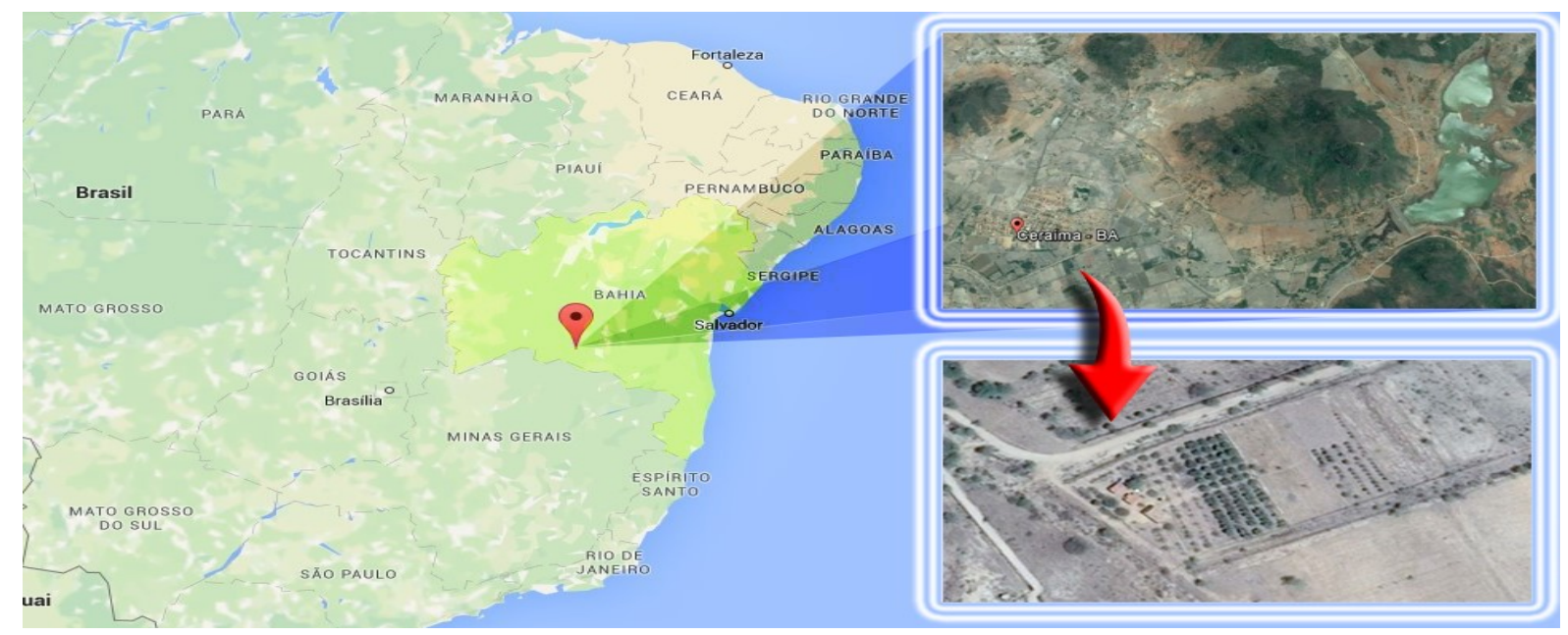

Figure 1. Study area, Ceraíma, Guanambi, Bahia, Brazil.

Table 1. Physical characteristics of Neosol Fulvic in the experimental area.

\begin{tabular}{|c|c|c|c|c|}
\hline \multirow{2}{*}{ Physical characteristics } & \multicolumn{4}{|c|}{ Depth (m) } \\
\hline & $0-0.25$ & $0.25-0.50$ & $0.50-0.75$ & $0.75-1.00$ \\
\hline Coarse sand $\left(\mathrm{g} \cdot \mathrm{kg}^{-1}\right)^{1}$ & 80 & 50 & 10 & 0 \\
\hline Fine sand $\left(\mathrm{g} \cdot \mathrm{kg}^{-1}\right)^{1}$ & 410 & 430 & 760 & 160 \\
\hline Silt $\left(g \cdot \mathrm{kg}^{-1}\right)^{2}$ & 270 & 280 & 120 & 520 \\
\hline Clay $\left(\mathrm{g} \cdot \mathrm{kg}^{-1}\right)^{2}$ & 240 & 240 & 110 & 320 \\
\hline Bulk density $\left(\mathrm{kg} \cdot \mathrm{dm}^{-3}\right)^{3}$ & 1.62 & 1.38 & 1.34 & 1.31 \\
\hline Water retention at $-10 \mathrm{kPa}\left(\mathrm{m}^{3} \cdot \mathrm{m}^{-3}\right)^{4}$ & 0.43 & 0.37 & 0.19 & 0.54 \\
\hline Water retention at $-1500 \mathrm{kPa}\left(\mathrm{m}^{3} \cdot \mathrm{m}^{-3}\right)^{4}$ & 0.15 & 0.12 & 0.05 & 0.16 \\
\hline
\end{tabular}

${ }^{1}$ By soil screening; ${ }^{2}$ Pippete method; ${ }^{3}$ Test tube and volumetric ring method; ${ }^{4}$ Porous plate equipment. 
"Tommy Atkins" is one of the varieties of mango that is most globally cultivated for exportation. The majority of cultivated mango in the valley of São Francisco, Brazil, is Tommy Atkins, which represents approximately 95\% of the mango crops [3]. The fruits are well received by the Brazilian fruit market as well as for exportation and as raw material for the industry. The fruits also last a relative long time after harvesting, which is a very positive feature when selling out the fruits. These features related to the Brazilian semiarid region justify the use of this variety in this study.

Crop practices commonly used in the region were done in the conduction of the experiment. After harvesting in January of 2011, pruning followed by fertilizer application of $500 \mathrm{~g}$ of MAP (monoammonium phosphate), $200 \mathrm{~g}$ of ammonium sulfate, $150 \mathrm{~g}$ of potassium chloride and $20 \mathrm{~kg}$ of chicken manure on each plant. The irrigation was performed on a daily basis over a period in which the plant emitted two vegetative shoots. After emitting the shoots, there was an application of growth regulation, Paclobutrazol. Afterward, the irrigation was ceased and when the plants exhibited symptoms of epinasty [14], calcium nitrate was applied to the leaves to break the dormancy of the buds and to induce a uniform flowering. After flowering, treatments of PRD were applied.

Five treatments were applied: from the beginning of flowering to harvesting of mango irrigated by drip irrigation: 01 -full irrigation, $100 \%$ of ETc; $02-100 \%$ of ETc, alternation of the irrigation side (FA) at every 15 days; $03-80 \%$ of ETc with FA of 15 days; $04-60 \%$ of ETc with FA of 15 days. A randomized block design was used, with six replicates and each plant represented an experimental plot.

Treatments were applied by varying irrigation time through control valves, which each valve referred to a different treatment. The irrigation was performed based on the evapotranspiration of reference (ETo) that was determined daily by the Penman-Monteith method, FAO standard method [17], using data from an automatic weather station installed near the orchard. The crop coefficient (Kc) used in the calculation of evapotranspiration during the assessment phases ranged between 0.45 and 0.87 as used by [18].

The climate changes throughout the experiment influenced on the evapotranspiration of reference (ETo) as depicted in Figure 2. The solar radiation was estimated by the Hargreaves Equation (1) due to the unviability of data of insolation.

\subsection{Irrigation Management}

The evapotranspiration of the crop (ETc) in mm for the irrigation was calculated by Equation (1).

$$
E T C=E T o \times K c
$$

where,

ETo is the evapotranspiration of reference in $\mathrm{mm}$ and

$K c$ is the coefficient crop.

The irrigation time per day used to manage the irrigation at the orchard over the experiment was calculated by using the Equation (2), which was recommended by [19].

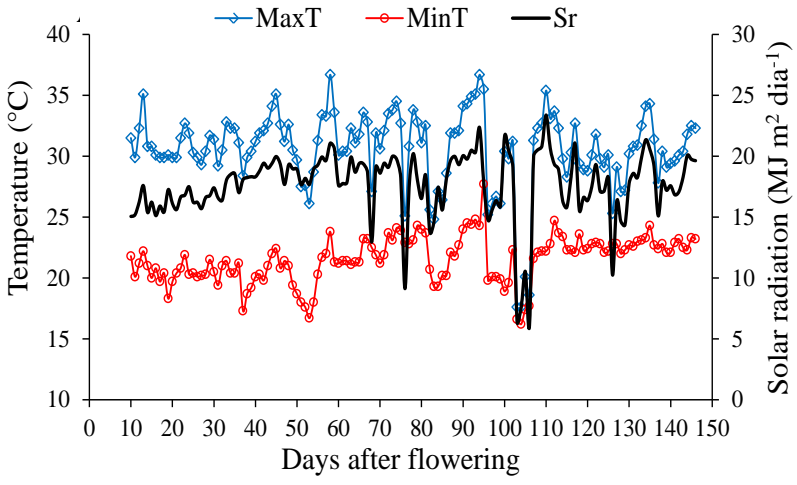

(a)

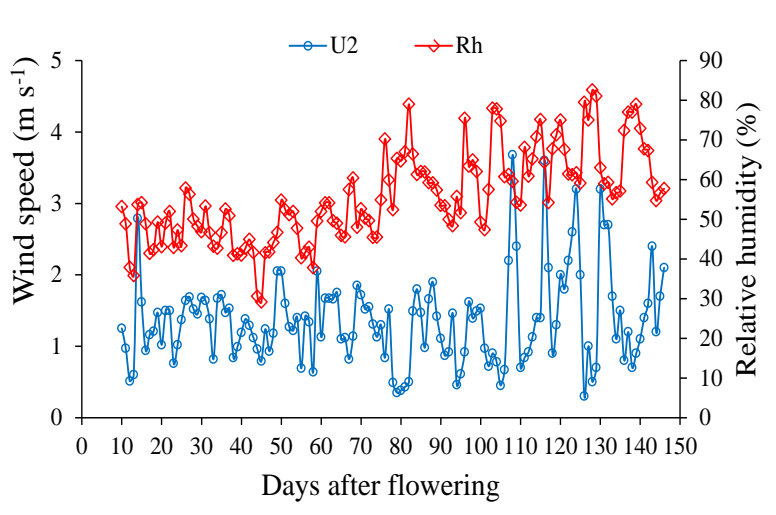

(b)

Figure 2. Maximum temperature-MaxT, minimum temperature-MinT and solar radiation-Sr (a) and average wind speed $\mathrm{U} 2$ and relative humidity-Rh (b) during the assessment period. August $1^{\text {st }}$ represented the second day after flowering. Guanambi, Bahia, Brazil, 2011. 


$$
T i=\frac{E T c \times R p \times E_{1} \times E_{2} \times K_{l}}{n \times q \times E a}
$$

where,

$T i$ is the irrigation time $\left(\mathrm{h} \cdot \mathrm{d}^{-1}\right)$.

$R p$ is the ETc replacement according to the treatment (decimal).

$E_{1}$ is the space between plant rows (m).

$E_{2}$ is the space between plants in the row (m).

$K_{1}$ is the localization coefficient.

$n$ is the number of emitters per plant.

$q$ is the drip flow rate $\left(\mathrm{L} \cdot \mathrm{h}^{-1}\right)$.

$E a$ is the application efficiency (decimal).

The $K_{1}$ values were calculated considering the area shaded by the plant, in accordance with [20], obtaining a unitary value.

The total applied water in the different treatments was $345.06 \mathrm{~mm}$ for the treatments 1 and 2; $276.04 \mathrm{~mm}$ for T3; $207.03 \mathrm{~mm}$ for T4 and $138.02 \mathrm{~mm}$ for T5, as shown in Figure 3. When it happened to rain, this quantity was subtracted from the ETc to obtain the irrigation time. It can be seen in Figure 3 that after the $115^{\text {th }}$ days after flowering, irrigation was not done because the occurrence of rain met the evapotranspiration requirement of the crop

\subsection{Analyzed Variables}

The physiological variables were measured with the aid of infrared gas analyzer (IRGA) model Lcpro ${ }^{+}$ Portable Photosynthesis System (ADC BioScientific Limited, UK) with temperature and ambient irradiance and airflow of $200 \mathrm{ml} \cdot \mathrm{min}^{-1}$. They were measured photosynthetically active radiation incident on the leaf (Qleaf) expressed in $\mu \mathrm{mol} \cdot \mathrm{m}^{-2} \cdot \mathrm{s}^{-1}$ ofphotons, leaf temperature $(\mathrm{Tl})$ in ${ }^{\circ} \mathrm{C}$, internal concentration of $\mathrm{CO}_{2}(\mathrm{Ci})$, $\mu \mathrm{mol} \cdot \mathrm{mol}^{-1}$, stomatal conductance $(g s)$, mol m${ }^{-2} \cdot \mathrm{s}^{-1}$, transpiration $(E) \mathrm{mmol} \cdot \mathrm{m}^{-2} \cdot \mathrm{s}^{-1}$ de $\mathrm{H}_{2} \mathrm{O}$, liquid photosynthesis $(A) \mu \mathrm{mol} \cdot \mathrm{m}^{-2} \cdot \mathrm{s}^{-1}$ de $\mathrm{CO}_{2}$, Instant water-use efficiency $(A / E)$, carboxylation efficiency $(A / C i)$ and quantum efficiency of photosynthesis (A/Qleaf). The measurements were performed before the occurrence of rainy season with 73 days after flowering between 10:00 a.m. and 12:00 p.m. in October 2011.

The water use efficiency (WUE) was calculated considering the yield and gross water applied for the treatments, according to Equation (3).

$$
W U E=\frac{Y}{G W A}
$$

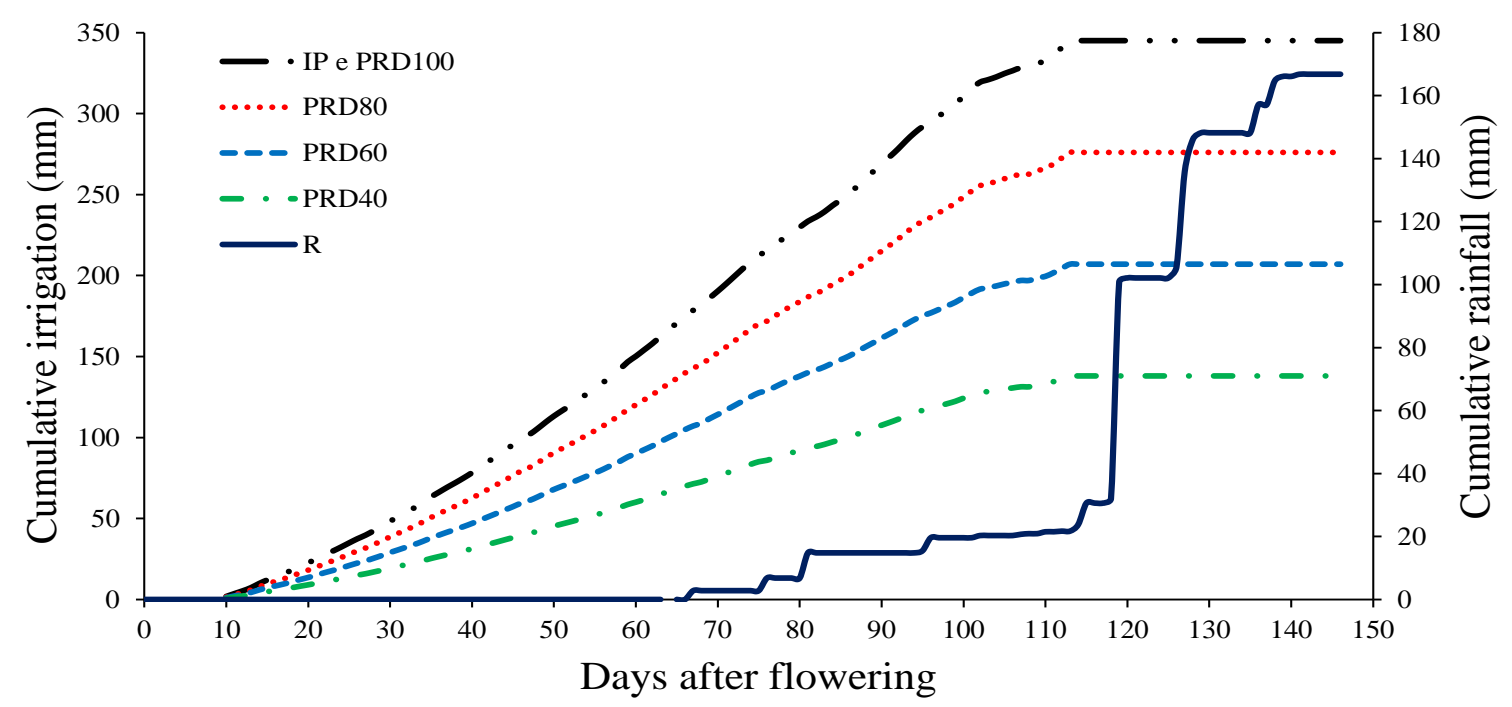

Figure 3. Cumulative irrigation applied to the different treatments and cumulative rainfall occurred during the experiment. Guanambi, Bahia, Brazil, 2011. 
where,

WUE: in $\mathrm{kg} \cdot \mathrm{ha}^{-1} \cdot \mathrm{mm}^{-1}$.

$Y$ : the yield, $\mathrm{kg} \cdot \mathrm{ha}^{-1}$.

GWA: the water applied in mm.

The obtained data of number of fruits per hectare, yield $\left(\mathrm{t} \cdot \mathrm{ha}^{-1}\right)$, water use efficiency and physiological variables were subjected to analysis of variance and means were compared using the Tukey test at $5 \%$ of probability.

\section{Results and Discussion}

The use of PRD caused no significant reduction in the production (number of fruits per hectare and yield) of the "Tommy Atkins" mango compared to full irrigation (Table 2). The physiological variables measured in "Tommy Atkins" were not affected by treatments based on the PRD $(P>0.05)$. [7] point out that when the water deficit in the soil is not very sharp, changes in stomatal conductance follow the same trend of the plants without water deficit and the reduction by $50 \%$ of ETc in the mango crop does not cause significant reduction in transpiration. However, a reduction of $24.20 \%$ in transpiration in plants subjected to regulated deficit irrigation (RDI) compared to full irrigation in the fruit expansion phase.

The reduction in transpiration rate in leaves of plants under water deficit can be explained by adaptation of the crop to avoid water loss [7]. [21] points out that as the soil water becomes scarce, the plant begins to reduce its transpiration rate to decrease the loss of water and to save available water in the soil. This probably occurs because of the stomatal closure caused by a signal emitted by the roots, synthesis of the plant hormone abscisic acid (ABA) and transport to the shoot via the xylem in response to water deficit in the soil. [22] emphasizes that this mechanism keeps the water in the plant, however interferes with the assimilation of $\mathrm{CO}_{2}$, and hence in yield. In this study, it was found that with higher water deficit, associated with switching, that is PRD at $40 \%$ of ETc,

Table 2. Number of fruits per hectare-NF, Yield $-Y\left(\mathrm{t} \cdot \mathrm{ha}^{-1}\right)$, Water-use efficiency-WUE $\left(\mathrm{kg} \cdot \mathrm{ha}^{-1} \cdot \mathrm{mm}^{-1}\right)$, Photosynthetically active radiation incident on the leaf-Qleaf $\left(\mu \mathrm{mol}\right.$ of photons $\left.\mathrm{m}^{-2} \cdot \mathrm{s}^{-1}\right)$, Leaf temperature- $\mathrm{Tl}\left({ }^{\circ} \mathrm{C}\right)$, Internal concentration of $\mathrm{CO}_{2}-\mathrm{Ci}\left(\mu \mathrm{mol} \cdot \mathrm{mol}^{-1}\right)$, transpiration $-E\left(\mathrm{mmol} \cdot \mathrm{m}^{-2} \cdot \mathrm{s}^{-1}\right)$, Stomatal conductance $-g \mathrm{~s}\left(\mathrm{~mol} \cdot \mathrm{m}^{-2} \cdot \mathrm{s}^{-1}\right)$, Photosynthesis$A\left(\mu \mathrm{mol} \cdot \mathrm{m}^{-2} \cdot \mathrm{s}^{-1}\right)$ and Carboxylation efficiency-A/Ci $\left(\mu \mathrm{mol} \cdot \mathrm{m}^{-2} \cdot \mathrm{s}^{-1} / \mu \mathrm{mol} \cdot \mathrm{mol}^{-1}\right)$, Quantum efficiency of photosynthesisA/Qleaf $\left(\mu \mathrm{mol}\right.$ de $\mathrm{CO}_{2} \mathrm{~m}^{-2} \cdot \mathrm{s}^{-1} / \mu \mathrm{mol}$ of photons $\left.\mathrm{m}^{-2} \cdot \mathrm{s}^{-1}\right)$ and Instant water-use efficiency-A/E $\left(\mu \mathrm{mol} \cdot \mathrm{m}^{-2} \cdot \mathrm{s}^{-1} / \mathrm{mmol}^{-2} \cdot \mathrm{m}^{-2} \cdot \mathrm{s}^{-1}\right)$ in “Tommy Atkins” mango fruit subjected to different strategies of partial rootzone drying irrigation, PRD. Guanambi, Bahia, Brazil, 2011.

\begin{tabular}{|c|c|c|c|c|c|c|}
\hline \multirow{2}{*}{ Characteristics } & \multicolumn{5}{|c|}{ Treatments } & \multirow{2}{*}{$\mathrm{CV}$} \\
\hline & FI & PRD100 & PRD80 & PRD60 & PRD40 & \\
\hline NF & $50058.00 \mathrm{AB}$ & $53,902.67 \mathrm{~A}$ & 32,796.33B & $38,079.33 \mathrm{AB}$ & $36,972.00 \mathrm{AB}$ & 27.26 \\
\hline $\mathrm{Y}$ & $24.00 \mathrm{AB}$ & 26.37A & 15.41B & 16.49B & $17.00 \mathrm{AB}$ & 27.93 \\
\hline WUE & 69.55B & $76.41 \mathrm{~B}$ & $55.83 B$ & 79.64B & 123.17A & 25.04 \\
\hline Qleaf & 1645.33 & 1405.72 & 1589.44 & 1573.06 & 1445.44 & 24.13 \\
\hline $\mathrm{Tl}$ & 40.88 & 40.28 & 40.26 & 40.70 & 40.58 & 2.58 \\
\hline $\mathrm{Ci}$ & 241.94 & 231.50 & 227.61 & 242.39 & 220.50 & 5.54 \\
\hline E & 5.40 & 5.30 & 4.80 & 4.56 & 3.83 & 21.48 \\
\hline gs & 0.20 & 0.19 & 0.17 & 0.16 & 0.13 & 31.65 \\
\hline$A$ & 9.51 & 10.08 & 9.61 & 8.02 & 8.01 & 24.55 \\
\hline$A / C i$ & 0.04 & 0.04 & 0.04 & 0.03 & 0.04 & 26.46 \\
\hline A/Qleaf & 0.006 & 0.009 & 0.007 & 0.006 & 0.016 & 153.50 \\
\hline$A / E$ & 1.82 & 2.08 & 2.21 & 1.93 & 2.15 & 16.64 \\
\hline
\end{tabular}

Means followed by the same letters in the line do not differ significantly at 5\% probability by Tukey test. FI—full irrigation, $100 \%$ of ETc; 02 - $100 \%$ of ETc, alternation of the irrigation side (FA) at every 15 days; 03-80\% of ETc with FA of 15 days; $04-60 \%$ of ETc with FA of 15 days. 
there was no reduction in yield. It is a very important fact from a sustainable standpoint, because productivity was satisfactory, enabling high and greater water-use efficiency, reaching up an increase of $77.10 \%$ in the WUE compared to full irrigation; i.e. increasing water productivity.

The rise in stomatal conductance ( $g s$ ) causes increase in transpiration, photosynthesis and in carboxylation efficiency. The $g s$ is responsible by the entering of $\mathrm{CO}_{2}$ and the release of water by the stomata; the larger is its opening, the smaller is the stomatal resistance and, consequently, there is increase in transpiration [22].

The eco-physiological behavior is a result of the balance of several environmental factors and not a single factor. The optimal temperature for the carboxylation of $\mathrm{CO}_{2}$ by the enzyme rubisco, ribulose-1,5-bisphosphate carboxylase/oxygenase is $22^{\circ} \mathrm{C}$. This enzyme prevails in plants with photosynthetic mechanism $\mathrm{C}_{3}$, such as the mango tree. The balance between the activities of carboxylase and oxygenase of the rubisco is maintained by the kinetic properties of the enzyme, temperature, and concentration of $\mathrm{CO}_{2}$ and $\mathrm{O}_{2}$. Under concentration of environmental $\mathrm{CO}_{2}$, an increase in the temperature modifies the kinetic constants of the rubisco and increases the oxygenation rate, preferably, the carboxylation [22], that is, it increases the photorespiration with decrease in the net photosynthesis rate of the plant. In general, below $30^{\circ} \mathrm{C}$, the quantum productivity of the photosynthesis, mol of $\mathrm{CO}_{2}$ fixed per absorbed quantum, in $\mathrm{C}_{3}$ plants is usually high and, above this limit, it falls significantly.

The results of production obtained in this study are in accordance with the ones showed by [11], who worked with PRD in a "Kent" mango orchard in the semiarid of Bahia and a reduction of 50\% of applied water was accomplished without any significant reduction in yield with alternation of PRD of 14 and 21 days. This research also agrees with [12] [13] who claim that is possible to obtain a sustainable production with the use of PRD at $50 \%$ of the ETc and a deficit irrigation at 30\% to 50\% results in a high efficient use of water with big savings of this resource. Table 2 indicates that the treatment 05 (PRD with $40 \%$ of ETc) with productivity of $17.00 \mathrm{t}^{\circ} \mathrm{ha}^{-1}$ results in higher efficiency of water use.

The study demonstrates that the partial rootzone drying (PRD) with $40 \%$ of ETc and alternation of the watered side at every 15 days do not cause significant reduction in productivity and increase a water use efficiency (WUE) $(P<0.05$ by Tukey test, as can be seen in Table 2). The use of PRD, with different hydric replenishments did not significantly affect the photosynthetically active radiation incident on the leaf, Qleaf; leaf temperature $\mathrm{Tl}$; internal concentration of $\mathrm{CO}_{2}, \mathrm{Ci}$; transpiration, $E$; stomatal conductance, gs; photosynthesis, $A$; carboxylation efficiency, $A / C i$; quantum efficiency of photosynthesis, A/Qleaf and instant water-use efficiency, $A / E$. The increase in leaf temperature causes reduction in A/Qleaf and $A / E$, however, increasing transpiration. The increase in $g s$ results in higher $E, A$ and $A / C i$ (Figures 4(d)-(f)).

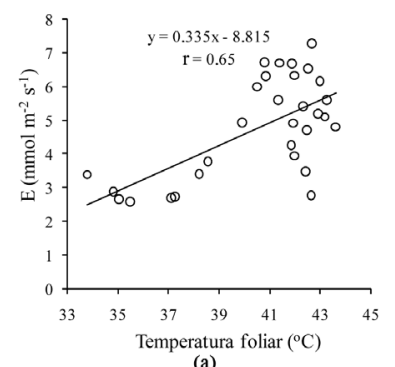

(a)

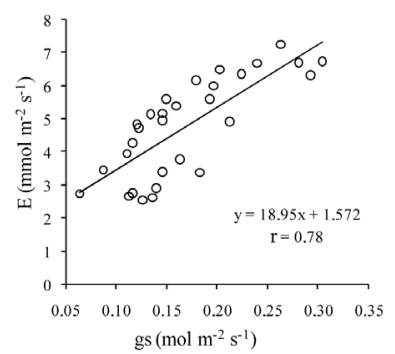

(d)

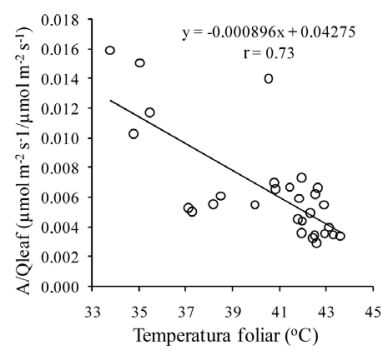

(b)

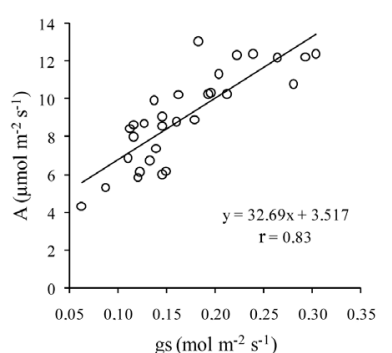

(c)

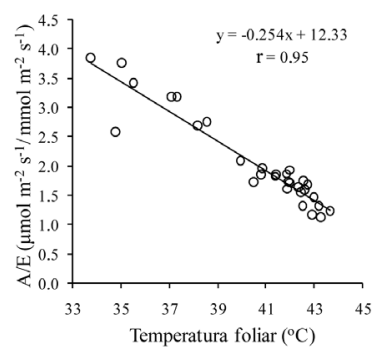

(c)

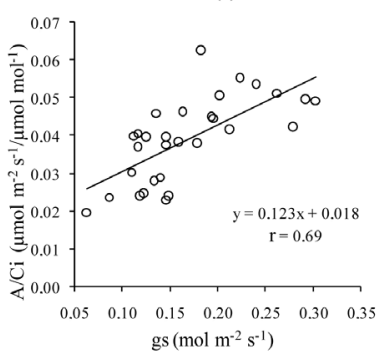

(f)

Figure 4. Transpiration- $E\left(\mathrm{mmol} \cdot \mathrm{m}^{-2} \cdot \mathrm{s}^{-1}\right)$, Quantum efficiency of photosynthesis-A/Qleaf ( $\mu \mathrm{mol}$ de $\mathrm{CO}_{2} \mathrm{~m}^{-2} \cdot \mathrm{s}^{-1} / \mu \mathrm{mol}$ of photons $\mathrm{m}^{-2} \cdot \mathrm{s}^{-1}$, Instant water-use efficiency- $A / E\left(\mu \mathrm{mol} \cdot \mathrm{m}^{-2} \cdot \mathrm{s}^{-1} / \mathrm{mmol} \cdot \mathrm{m}^{-2} \cdot \mathrm{s}^{-1}\right)$ according to the leaf temperature, transpiratio- $E(\mathrm{D})\left(\mathrm{mmol} \cdot \mathrm{m}^{-2} \cdot \mathrm{s}^{-1}\right)$, photosynthesis- $A\left(\mu \mathrm{mol} \cdot \mathrm{m}^{-2} \cdot \mathrm{s}^{-1}\right)$ and carboxylation efficiency-A $/ C i(\mathrm{~F})\left(\mu \mathrm{mol} \cdot \mathrm{m}^{-2} \cdot \mathrm{s}^{-1} / \mu \mathrm{mol} \cdot \mathrm{mol}^{-1}\right)$ according to the stomatal conductance- $-g s\left(\mathrm{~mol} \cdot \mathrm{m}^{-2} \cdot \mathrm{s}^{-1}\right)$ in “Tommy Atkins" mango. Guanambi, Bahia, Brazil, 2011. 
The theory of using partial rootzone drying bases on the fact that the hydric deficit in the soil induces the production of abscisic acid (ABA) by the roots that is transported through the vascular system, concentrating in the shoot, promoting the partial closing of the stomata, controlling the vegetative growth and, consequently, reducing the water loss to the atmosphere. This fact is partially verified by the values of stomatal conductance- $g s$ and transpiration $-E$ (Table 2), in which, despite not differing statistically, the means of $g s$ and $E$ fall as the applied water reduces in the PRD.

\section{Conclusion}

It can be concluded with the present paper that the use of PRD with $40 \%$ of ETc causes no interference on the gas exchange in "Tommy Atkins" mango, maintaining the yield and increasing the efficiency of water use.

\section{Acknowledgments}

The authors are grateful to the Instituto Federal Baiano for the financial support and the IF Baiano Campus Guanambi for providing the area, materials and its staff to enable the conduction of this study.

\section{References}

[1] IBGE (2014) Banco de Dados Agregados. Sistema IBGE de Recuperação Automática—SIDRA. http://www.ibge.gov.br

[2] Manica, I. (2001) Clima e solo. In: Manica, I., Icuma, I.M., Malavolta, E., Ramos, V.H.V., Oliveitra Junior, M.E., Cunha, M.M. and Junqueira, N.T.V., Eds., Manga: Tecnologia, Produção, Pós-colheita, Agroindústria e Exportação, CincoContinentes, Porto Alegre, 617 p.

[3] Lima Neto, F.P., Santos, C.A.F. and Costa, J.G. (2010) Cultivo da mangueira: Cultivares. Embrapa Semiárido Sistemas de Produção, 2 - $2^{a}$ edição. Versão Eletrônica.

[4] Santos, M.R.; Martinez, M.A.; Donato, S.L.R.; Coelho, E.F. (2014) Fruityieldand Root System Distributionof “Tommy Atkins” Mango Underdifferentirrigation Regimes. Revista Brasileira de Engenharia Agrícola e Ambiental, 18, 362-369. http://dx.doi.org/10.1590/S1415-43662014000400002

[5] Santos, M. R., Martinez, M.A., Donato, S.L.R. and Coelho, E.F.(2014) Tommy Atkins Mango Yield and Photosynthesis under Hydric Deficit in Semiarid Region of Bahia. Revista Brasileira de Engenharia Agrícola e Ambiental, 18, 899907. http://dx.doi.org/10.1590/1807-1929/agriambi.v18n09p899-907

[6] Santos, M.R. and Martinez, M.A. (2013) Soil Water Distribution and Extraction by "Tommy Atkins” Mango (Mangiferaindica L.) Trees under Different Irrigation Regimes. Idesia, 31, 7-16. http://dx.doi.org/10.4067/S0718-34292013000300002

[7] Santos, M.R., Martinez, M.A. and Donato, S.L.R. (2013) Gas exchanges of “Tommy Atkins” Mango Trees under Different Irrigation Treatments. Bioscience Journal, 29, 1141-1153.

[8] Sampaio, A.H.R., Coelho Filho, M.A., Coelho, E.F., Daniel, R., Oliveira, V.V.M., Carvalho, G.C. and Santana Junior, E.B. (2010) Déficit hídrico e secamento parcial do sistema radicular em pomar de lima ácida. Pesquisa agropecuária Brasileira, 45, 1141-1148. http://dx.doi.org/10.1590/S0100-204X2010001000013

[9] Kang, S.Z. and Zhang, J. (2004) Controlled Alternate Partial Root-Zone Irrigation: Its Physiological Consequences and Impact on Water Use Efficiency. Journalof Experimental Botany, 10, 1-10. http://dx.doi.org/10.1093/jxb/erh249

[10] Mccarthy, M.G. (2000) Regulated Deficit Irrigation and Partial Rootzone Drying as Irrigation Management Techniques for Grapevines. Deficit Irrigation Practices, Water Reports No. 22, 79-87, FAO, Roma.

[11] Sant'Ana, J.A.V., Coelho Filho, M.A., Coelho, E.F., Cunha Alves, A.A., Oliveira, V.V.M. and Velame, L.M. (2009) Manejo de irrigação com déficit (PRD) em pomar de manga "Kent” no semi-árido baiano. $3^{a}$ Jornada Científica. Embrapa Mandioca e Fruticultura Tropical, Resumos. Cruz das Almas, 17 a 20 de Agosto de 2009.

[12] Spreer, W., Nagle, M., Neidhart, S., Carle, R., Ongprasert, S. and Muller, J. (2007) Effect of Regulated Deficit Irrigation and Partial Rootzone Drying on the Quality of Mango Fruits (MangiferaindicaL., cv. "Chok Anan”). Agricultural Water Management, 88, 173-180. http://dx.doi.org/10.1016/j.agwat.2006.10.012

[13] Spreer, W., Ongprasert, S., Hegele, M., Wunsche, J.N. and Muller, J. (2009) Yield and Fruit Development in Mango (MangiferaindicaL. cv. Chok Anan) under Different Irrigation Regimes. Agricultural Water Management, 96, 574584. http://dx.doi.org/10.1016/j.agwat.2008.09.020

[14] Mouco, M.A.C. and Albuquerque, J.A.S. (2005) Efeito do paclobutrazol em duas épocas de produção da mangueira. Bragantia, 64, 219-225. http://dx.doi.org/10.1590/S0006-87052005000200008 
[15] Silva, V.P.R., Campos, J.H.B.C. and Azevedo, P.V. (2009) Water-Use Efficiency and Evapotranspiration of Mango Orchard Grown in Northeastern Region of Brazil. ScientiaHorticulturae, 120, 467-472. http://dx.doi.org/10.1016/j.scienta.2008.12.005

[16] Carmo, R.L., Ojima, A.L.R.O., Ojima, R. and Nascimento, T.T. (2007) Água virtual, escassez e gestão: O Brasil como grande "exportador" de água. Ambiente \& Sociedade, 10, 83-96. http://dx.doi.org/10.1590/S1414-753X2007000200006

[17] Allen, R.G., Pereira, L.S., Raes, D. and Smith, M. (1998) Crop Evapotranspiration: Guidelines for Computing Crop Water Requirements. FAO Irrigationand Dranaige Paper No. 56 FAO, Rome, 300 p.

[18] Cotrim, C.E., Coelho Filho, M.A., Coelho, E.F., Ramos, M.M. and Cecon, P.R. (2011) Regulated Deficit Irrigation and Tommy Atkins Mango Orchard Productivity under Microsprinkling in Brazilian Semi Arid. EngenhariaAgrícola, 31, 1052-1063. http://dx.doi.org/10.1590/S0100-69162011000600003

[19] Goodwin, I. and Boland, A.M. (2000) Scheduling Deficit Irrigation of Fruit Trees for Optimizing Water Use Efficiency. Deficit Irrigation Practices, Water Reports No. 22, 67-78, FAO, Roma.

[20] Bernardo, S., Soares, A.A. and Mantovani, E.C. (2006) Manual de Irrigação. 8th edition, Editora UFV, Viçosa, 625 p.

[21] Castro Neto, M.T. (2003) Efeito do déficit hídrico na transpiração e resistência estomática da mangueira. Revista Brasileira de Fruticultura, 25, 93-95. http://dx.doi.org/10.1590/S0100-29452003000100027

[22] Taiz, L. and Zeiger, E. (2009) Fisiologia Vegetal. 4 Edtiion, Artmed, Porto Alegre, 848 p. 